\title{
МЕТОДИЧНІ УМОВИ ПІДГОТОВКИ МАЙБУТНЬОГО ВЧИТЕЛЯ ДО РЕАЛІЗАЦІЇ ПРИНЦИПІВ ДЕМОКРАТИЧНОЇ ОСВІТИ НА УРОКАХ ТРУДОВОГО НАВЧАННЯ
}

\author{
Володимир Стешенко \\ доктор педагогічних наук, професор, \\ професор кафедри теорії та практики технологічної і професійної освіти ДВНЗ \\ «Донбаський державний педагогічний університет», \\ м. Слов'янськ, Україна \\ ORCID ID 0000-0002-8183-3957 \\ steshenko.volodymyr@gmail.com \\ Альона Нестеренко \\ аспірант кафедри теорії та практики технологічної і професійної освіти \\ ДВНЗ «Донбаський державний педагогічний університет» \\ м. Слов'янськ Донецької області, Україна \\ ORDID ID 0000-0002-5533-1080 \\ nesterenko.as@ukr.net

\begin{abstract}
Анастасія Шаповалова
учитель інформатики Парасковіївської ЗОШ I - III ст. Бахмутського району

с. Парасковіївка Донецької області, Україна

ORDID ID 0000-0003-1553-5350

nasta.shapovalova.2000@gmail.com
\end{abstract}

\begin{abstract}
Анотація. У статті проаналізовано зміст понять педагогічна й методична умова у загальному значенні та в процесі підготовки майбутнього вчителя трудового навчання. Визначено й розкрито сутність методичних умов підготовки майбутнього вчителя до реалізації принципів демократичної освіти на уроках трудового навчання, до яких віднесено: визначення та збагачення змісту навчальних дисциплін загальнонаукового, загально педагогічного циклів й курсу теорія і методика трудового навчання та технології відповідними знаннями; розробка та запровадження вибіркового курсу «Основи демократизації технологічної освіти»; розробка тематики курсових робіт з проблем реалізації демократичної освіти в освітньому процесі 33СО, розробка для студентів методичних вказівок щодо реалізації принципів демократичної освіти на уроках трудового навчання під час проходження педагогічної практики в школі.
\end{abstract}

Ключові слова: майбутній вчитель трудового навчання; методичні умови; педагогічні умови; принципи демократичної освіти.

Постановка проблеми в загальному вигляді. В організації освітнього процесу у закладах вищої педагогічної освіти особливе місце відводиться педагогічним умовам, які забезпечують ефективну підготовку майбутніх 
педагогів до педагогічної діяльності. Під педагогічними умовами вчені розуміють в різних аспектах. Так, одні розглядають їх як обставини, що визначають стан і розвиток функціонуючих педагогічних систем (Сластенин, 2002); інші - як обставини, що зумовлюють цілісний продуктивний педагогічний процес професійної підготовки фахівців, що опосередковується активністю особистості, групою людей (Семенова, 2006); ще інші - як обставини, що сприяють ефективному (нормальному) функціонуванню педагогічного процесу (Стешенко, 2018).

Формування готовності майбутнього вчителя до реалізації принципів демократичної освіти на уроках трудового навчання передбачає визначення таких педагогічних умов, які б сприяли розвитку їх здатності до створення на уроках трудового навчання демократичного освітнього простору, атмосфери співробітництва, реалізації демократичних форм і методів тощо.

Аналіз останніх досліджень i публікацій. Проблемі визначення педагогічних умов в аспекті демократизації освітнього процесу присвячено праці багатьох учених. Так, зокрема, Т. Сергеева (2011) досліджувала педагогічні умови формування демократичних ціннісних орієнтацій у майбутніх учителів. 3. Мусакаєва (2006) досліджувала педагогічні умови забезпечення гуманізації й демократизації внутрішньо шкільного управління, які сприяють переорієнтації суб'єктів педагогічної діяльності на індивідуальну роботу, забезпеченню методами та прийомами особистісного підходу суб'єкта освітньої діяльності (вчителя) до об'єкта (учня) при оволодінні учнями засобами самоорганізації і самовизначення). Г. Назаренко (2016) розкрила організаційно-педагогічні умови виховання культури демократизму в учнів старших класів закладів загальної середньої освіти під час демократичної взаємодії старшокласників з інститутами громадянського суспільства, органами влади та місцевого самоврядування.

I. Хуторянський (2000) визначив педагогічні умови демократизації системи загальної освіти на рівні муніципалітету, освітнього закладу, вчительського колективу та окремого учня. Д. Макхамов (2012) виділив та експериментально перевірив педагогічні умови демократизації педагогічного процесу в закладах середньої професійної освіти та педагогічних коледжах засобами студентського самоуправління, інноваційних технологій навчання із забезпеченням особистісного розвитку суб'єктів освітнього процесу, максимальній свободі студента та ін.

Слід також відзначити, що науковці систематизували педагогічні умови відповідно до провідних видів діяльності. Так, в роботі (Стешенко, 2018) запропоновано розглядати педагогічні умови, як обставини/причини, які 
обумовлюють/визначають ефективне (нормальне) функціонування предмета дослідження на основі здійснюваної освітньої діяльності (соціально-виховної, організаційної, дидактичної, методичної або їхнім поєднанням) у комплексі на основі діяльнісного, системного та інших методологічних підходів.

Отже, методичні умови є одним із різновидів педагогічних умов. Їх вчені пов'язують з розробкою змісту й організацією освітнього процесу (Будас, 2014; Стешенко, 2018). Наприклад, А. Будас (2014) визначив методичні умови як обставини, що забезпечують цілеспрямований вибір, конструювання й застосування елементів змісту та методів навчання, завдяки яким освітній процес $\epsilon$ ефективним. Тобто методичні умови науковець пов'язувала з середовищем, від якого залежить процес формування їхньої правової компетентності.

С. Моцак (2011) методичні умови трактувала як сукупність обставин, засобів, які сприяють організації ефективної пізнавальної діяльності учнів у процесі навчання. До них вчена віднесла заходи з мотивації, систематизації, індивідуалізації навчання, відбір змісту навчання тощо.

А. Бєляєва, О. Бирилова (2013) та ін. розглядали методичні умови як сукупність змісту, знань, умінь, цінностей, чинників, способів і засобів, що дозволяють реалізувати освітні цілі навчального предмета. На цих підставах О. Бирилова (2013) визначила комплекс методичних умов формування і розвитку загальнокультурних компетенцій бакалавра педагогічної освіти в галузі безпеки життєдіяльності. Це:

- змістовні, які забезпечують цілеспрямоване планування змісту освітнього процесу;

- процесуальні - сприяють взаємодії діяльності викладача і студентів на різних етапах освітнього процесу

- матеріально-технічні - забезпечують ефективність формування i розвитку здатностей студентів на різних етапах освітнього процесу.

Досліджуючи проблему професійної підготовки майбутнього вчителя трудового навчання методичні умови вчені визначали з різною метою. Але проблема визначення методичних умов підготовки майбутнього вчителя трудового навчання до реалізації принципів демократичної освіти на уроках трудового навчання ще не знайшла свого вирішення. Це й обумовило постановку мети даного дослідження.

Формулювання цілей статті (постановка завдання). Отже, мета статті полягає в тому, щоб визначити та розкрити сутність методичних умов підготовки майбутнього вчителя до реалізації принципів демократичної освіти на уроках трудового навчання.

Професіоналізм педагога: теоретичні й методичні аспекти. - Вип. 14 (Ч. 2). - Слов’янськ, 2021. 
Результати дослідження. Зважаючи на наявні в літературі тлумачення понять «педагогічні умови» та «методичні умови» методичні умови підготовки майбутнього вчителя до реалізації принципів демократичної освіти на уроках трудового навчання ми розглядаємо як обставини, що забезпечують комплексну сукупність потенційно містких методичних ресурсів і вихідних положень для оволодіння здобувачами освіти відповідними знаннями, вміннями, навичками, практичним досвідом і ціннісними відношеннями в процесі їх професійної підготовки. Очевидно, що такими ресурсами є зміст професійно-орієнтованих навчальних дисциплін і організація навчальної діяльності студентів, зокрема їх самостійна робота.

При визначенні методичних умов підготовки майбутнього вчителя до реалізації принципів демократичної освіти на уроках трудового навчання ми виходили із мети, завдань та змісту методики трудового навчання як навчальної дисципліни, яка досліджує закономірності організації вивчення відповідного навчального предмета, а саме: закономірності, принципи, зміст, форми, методи технологічної підготовки в усіх освітніх, розвивальних і виховних аспектах (Стешенко, 2018). Аналіз змісту професійно-орієнтованих навчальних дисциплін освітньої програми «Середня освіта (Трудове навчання та технології)» та організації освітнього процесу (зокрема самостійної роботи студентів) дав нам можливість визначити наступні методичні умови підготовки майбутнього вчителя до реалізації принципів демократичної освіти на уроках трудового навчання:

1) визначення та збагачення змісту навчальних дисциплін загальнонаукового та загально педагогічного циклів (філософії, вступу до спеціальності, педагогіки, психології, педагогічної та вікової психології, професійної та корпоративної етики та естетики) знаннями про сутність i особливості демократичної освіти;

2) визначення та збагачення змісту курсу теорії і методики трудового навчання та технології знаннями про методику реалізації принципів демократичної освіти на уроках трудового навчання;

3) розробку та запровадження вибіркового курсу «Основи демократизації технологічної освіти»;

4) розробку тематики курсових робіт $з$ педагогіки, теорії і методики трудового навчання та технології з проблем реалізації демократичної освіти в освітньому процесі 33СО; 
5) розробку для студентів методичних вказівок щодо реалізації принципів демократичної освіти на уроках трудового навчання під час проходження педагогічної практики в школі.

Розкриємо більш детально кожну з визначених нами дидактичних умов.

Так, згідно 3 першою дидактичною умовою курс «Філософія» ми пропонуємо збагатити такими відомостями:

- тему «Сучасна світова філософія» - знаннями про вплив вчення Дж. Дьюї на формування демократичного світогляду педагогів;

- тему «Традиції та особливості розвитку філософської думки в Україні» - знаннями про становлення демократичних поглядів педагогів на початку $\mathrm{XX} \mathrm{ст.}$

Курс «Психологія» пропонуємо збагатити такими відомостями:

- тему «Психологія особистості» - знаннями про особливості самоорганізації особистості;

- тему «Особистість у діяльності і спілкуванні» - знаннями про демократичний стиль спілкування вчителя з учнями і учнів між собою;

- тему «Предмет соціальної психології» - знаннями про толерантність в освітньому процесі та протидію булінгу.

Курс «Педагогічна та вікова психологія» збагатити:

- тему «Основні напрямки зарубіжної та вітчизняної вікової психології» відомостями про вплив демократичного освітнього середовища на становлення гуманістично-демократичних поглядів особистості учня на різних етапах розвитку; про погляди вчених-гуманістів при розкритті питання гуманістичної психології у працях (К. Роджерса, А. Маслоу, В. Франкла, С. Сатір, Ш. Бюлера) на зародження демократичних поглядів у підлітковому віці;

- тему «Психічний розвиток дитини від народження до вступу в школу» - знаннями про зародження демократичної взаємодії між людьми на ранніх етапах розвитку дитини;

- тему: «Психологія підлітка та старшокласника» - про толерантні відношення до оточуючих;

- тему «Загальна характеристика дорослого періоду життя» відомостями про особливості становлення демократичних поглядів майбутнього педагога в умовах студентської спільноти та молодіжних організаціях.

- тему «Психологія самовиховання та перевиховання. Психологічні аспекти роботи з важкими дітьми» - про роль еталону у процесі виховання та перевиховання, про роль демократичного освітнього середовища на становлення та реабілітацію (перевиховання) важких підлітків в 33СО;

Професіоналізм педагога: теоретичні й методичні аспекти. - Вип. 14 (Ч. 2). - Слов'янськ, 2021. 
- тему «Психологічний портрет особистості педагога в контексті педагогічної діяльності, педагогічного колективу та педагогічного спілкування» - про професійно-значущі демократичні ціннісні орієнтації вчителя, розвиток толерантності у майбутнього вчителя під час навчання в ЗВО.

В курсі «Вступ до спеціальності» необхідно додати:

- до теми «Вчитель трудового навчання» - відомості про важливість володіння вчителем поряд з іншими демократичною компетентністю та про роль демократичних відносин у процесі технологічної діяльності учнів;

- до теми «Професійне спілкування в структурі діяльності педагога» знання про демократичний стиль спілкування як ефективний метод взаємодії в школі (зокрема на уроках трудового навчання) та про демократичний спосіб управління учнівським колективом на уроках трудового навчання.

В курсі «Педагогіка» слід додати такі знання:

- до теми «Система освіти в Україні» відомості про сутність принципу демократизму як одного з основних принципів освіти в Україні;

- до теми «Розвиток та формування особистості» відомості про сутність демократичного освітнього середовища;

- до теми «Освіта і педагогіка в Україні у 1920-1990 рр.» інформацію про розвиток ідей демократизації змісту педагогічної освіти вчителя в Україні в різні періоди розвитку суспільства;

- до теми «Система освіти в Україні» інформацію про можливості педагогіки партнерства у формуванні демократичних цінностей в учнів в умовах Нової української школи;

- до теми «Форми організації навчання» інформацію про форми та методи організації освітнього процесу на демократичних засадах.

В курсі «Професійна та корпоративна етика та естетика» слід додати:

- до розділу «Становлення професійної та корпоративної етики та естетики» знання про переваги суб'єкт-суб'єктної взаємодії між учасниками освітнього процесу; та про толерантність, як необхідну рису сучасної людини, особливо вчителя, як провідного діяча у формуванні світогляду громадянина у демократичному суспільстві.

- до розділу «Морально-естетичні засади професійної та корпоративної етики та естетики» інформацію про різновиди толерантного відношення як ознаку професійної та корпоративної культури педагога; про морально-етичні якості людини у працях філософів, митців та провідних діячів Античності й Середньовіччя. 
Відповідно до другої дидактичної умови курс «Теорія і методика трудового навчання та технології» слід збагатити наступними відомостями:

- тему «Сучасний вчитель трудового навчання» - про роль вчителя трудового навчання у становленні особистості учня на уроках трудового навчання;

- тему «Проєктно-технологічна система трудового навчання як основа реалізації трудової підготовки в сучасній школі» - знаннями про важливість оволодіння майбутнім вчителем трудового навчання методикою організації освітнього процесу на демократичних основах;

- тему «Принципи дидактики в трудовому навчанні» - знаннями про принципи демократизації освітнього процесу та особливостями їх реалізації під час організації проєктно-технологічної діяльності;

- тему «Інтерактивні методи на уроках трудового навчання» відомостями про можливості інтерактивних методів реалізації принципів демократичної освіти на уроках трудового навчання та технологій;

- тему «Форми організації практичної роботи учнів на заняттях трудового навчання» - інформацією про форми організації освітнього процесу на основі демократичних принципів у процесі проєктної діяльності.

Відповідно до третьої дидактичної умови вибірковий курс «Основи демократизації технологічної освіти» повинен мати за мету забезпечення системної підготовки майбутнього вчителя трудового навчання до реалізації демократичної освіти на уроках трудового навчання в Новій українській школі.

Завданнями такого курсу мають бути:

1) формування позитивного відношення до використання в трудовій діяльності принципів демократичної освіти.

2) ознайомлення студентів із теоретико-методологічними засадами демократичної освіти;

3) формування системи знань про сутність принципів демократичної освіти;

4) оволодіння студентами вміннями з реалізації принципів демократичної освіти на уроках трудового навчання та технологій.

Зміст такого курсу має включати два розділи: теоретичний і практичний. Теоретичний має бути спрямованим на оволодіння студентами основними поняттями демократичної освіти: нормативно-правовим підгрунтям запровадження та реалізації демократичної освіти; принципами демократичної освіти (співробітництва, самоорганізації, різноманітності) в процесі трудового навчання НУШ. Практичний розділ - передбачати оволодіння цими основами на 
власному досвіді на практичних заняттях i в процесі самостійної роботи студентів.

Відповідно до четвертої дидактичної умови темами курсових робіт 3 педагогіки можуть бути:

1) Вплив поглядів вчених 20-30-х років XX століття на становлення демократичної освіти з початком розбудови незалежної України;

2) Особливості прагматичної педагогіки Дж. Дьюї;

3) Демократизація управління освітніми закладами;

4) Особливості демократичного освітнього середовища в старших класах;

5) Вимоги до педагога демократичної школи;

6) Формування толерантності учнів у процесі проведення виховних заходів тощо.

Темами курсових робіт з психології можуть бути:

1) Особливості самоорганізації учнів;

2) Психолого-педагогічний супровід самостійної роботи учнів 5-9 класів;

3) Демократичні ціннісні орієнтації педагога;

4) Психологічні передумови забезпечення атмосфери співробітництва в шкільному колективі та ін.

Темами курсових робіт 3 «Теорії i методики трудового навчання та технології» можуть бути:

1) Розвиток умінь в учнів 5-9 кл. 3 самоорганізації у процесі проектної діяльності;

2) Реалізація принципу співробітництва на уроках трудового навчання в 59 класах;

3) Реалізація методів демократичної освіти на уроках трудового навчання (як приклад метод «Е 5»);

4) Розвиток творчих здібностей учнів у процесі виконання проєкту на уроках трудового навчання та ін.

Щодо n’ятої дидактичної умови, під час проходження педагогічної практики студенти мають на практиці застосувати отримані знання з реалізації дидактичних принципів під час проведення пробних i залікових уроків. Для цього їх слід ставити завдання включення до планів-конспектів питань 3 організації та забезпечення демократичного освітнього середовища в класі, 3 використання демократичного стилю спілкування 3 учнями, 3 реалізації принципів різноманітності, співробітництва та самоорганізації на уроках трудового навчання та технології при виконанні учнями навчальних проектів тощо. 
Методичні умови підготовки майбутнього вчителя до реалізації принципів демократичної освіти на уроках трудового навчання

\section{Висновки 3 дослідження і перспективи подальших розвідок у цьому} напрямі. У результаті проведеного дослідження нами було визначено п'ять дидактичних умов ефективної підготовки майбутнього вчителя трудового навчання до реалізації принципів демократичної освіти. Комплексне їх застосування в освітньому процесі не тільки забезпечить послідовне й грунтовне формування в студентів здатності до формування в учнів культури демократичної взаємодії при виконанні різноманітних завдань, а й підвищить рівень їх інтересу до педагогічної діяльності.

Перспективи подальшого дослідження пов'язані з розробкою педагогічної технології реалізації визначених нами методичних умов 3 підготовки майбутнього вчителя трудового навчання в освітньому процесі закладів вищої педагогічної освіти.

\section{СПИСОК ВИКОРИСТАНИХ ДЖЕРЕЛ}

1. Будас, А. (2014). Методичні умови ефективності навчання правознавства студентів економічних спеціальностей. Збірник наукових праць Уманського держсавного педагогічного університету імені Павла Тичини, 2, 59-65.

2. Бырылова, Е.А., Авдеева, Н.В. (2013). Методические условия формирования и развития общекультурных компетенций у бакалавров педагогического образования в области безопасности жизнедеятельности. Молодой учёный, 8 (55), 380-383.

3. Коберник, О.М., Ящук, С.М. (2015). Наукові засади теорії та методики навчання технологій. Умань: ФОП «Жовтий».

4. Макхамов, Д. (2012). Демократизачия педагогического прочесса в средних профессиональных учебных заведениях. Основные тенденщии развития (на материалах педагогического и технического колледжа). (Дис. канд. пед. наук). Душанбе.

5. Моцак, C.I. (2011). Методичні основи організації позаурочної роботи з історії у профільних класах. (Дис. канд. пед. наук). Київ.

6. Мусакаева, 3.3. (2006). Педагогические условия гуманизаџии и демократизаџии внутришкольного управления. (Автореф. дис. канд. пед. наук). Махачкала.

7. Назаренко, Г.А. (2016). Теорія і практика виховання культури демократизму учнів старших класів загальноосвітніх навчальних закладів. (Дис. докт. пед. наук). Київ.

8. Сластенин, В.А., Исаев, И.Ф., Мищенко, А.И., Шиянов, Е.Н. (2002). Педагогика. Москва: Школьная Пресса.

9. Сергеева, Т.Н. (2011). Формирование демократических иееноотных ориентаций у будущего учителя. (Автореф. дис. канд. пед. наук). Нижний Новгород.

10. Словник-довідник з професійної педагогіки. (2006). Ред.-упоряд. А. В. Семенова. Одеса: «Пальміра».

11. Стешенко, В., Стешенко, Б. (2018). Фактори визначення педагогічних умов організації освітнього процесу в закладах вищої освіти. Професіоналізм педагога: теоретичні йметодичні аспекти, 8, 27-37.

12. Хуторянский, И.И. (2000). Педагогические условия демократизаџии муниципальной системы общего образования. (Дис. канд. пед. наук). Томск.

Професіоналізм педагога: теоретичні й методичні аспекти. - Вип. 14 (Ч. 2). - Слов’янськ, 2021. 


\title{
METHODOLOGICAL CONDITIONS OF THE FUTURE TEACHER TRAINING FOR IMPLEMENTING THE PRINCIPLES OF DEMOCRATIC EDUCATION IN LABOR TRAINING LESSONS
}

\author{
Volodymyr Steshenko \\ Doctor of Pedagogical Sciences, Professor, \\ Professor of the Department of Theory and Practice of \\ Technological and Vocational Education, \\ SHEI "Donbas State Pedagogical University" \\ Sloviansk, Donetsk region, Ukraine \\ ORCID ID 0000-0002-8183-3957 \\ steshenko.volodymyr@gmail.com
}

\author{
Alyona Nesterenko \\ PhD student of the Department of Theory and Practice of \\ Technological and Vocational Education \\ SHEI "Donbas State Pedagogical University" \\ Sloviansk, Donetsk region, Ukraine \\ ORDID ID 0000-0002-5533-1080 \\ nesterenko.as@ukr.net \\ Anastasia Shapovalova \\ teacher of Computer Science \\ Paraskoviivska Secondary School, \\ Paraskoviivka, Donetsk region, Ukraine \\ ORDID ID 0000-0003-1553-5350 \\ nasta.shapovalova.2000@gmail.com
}

\begin{abstract}
This article shows the relevance of the problem of identifying methodological conditions of preparing a future teacher to implement the principles of democratic education in the lessons of labor education, as well as analyzed the meaning of understanding the pedagogical and methodical conditions in the general meaning and in the preparation of a future teacher of labor education.

It is shown that methodical environment is one of the components of pedagogical conditions that contribute to the organization and improvement of the educational process for the purpose of equipping students with theoretical, practical, methodological knowledge and practical skills to use them due to the purposeful approach, design and implementation of the elements of content, methods (techniques), as well as organizational forms to achieve the goals of methodological training of future teachers of labor training.

The essence of didactic conditions of preparation of the future teacher for realization of principles of democratic education at labor training lessons were determined and revealed. They include: definition and enrichment of the content of educational disciplines of general scientific and pedagogical cycles by knowledge of essence and features of democratic education; definition and enrichment of the theory and methodology of labor training and techno; development and implementation the introduction of a selective course "Fundamentals of democratization of
\end{abstract}


technological education," which aims to provide a systematic training of future teachers of labor education to implement democratic education in the lessons of labor education in the New Ukrainian school; development of topics for term papers on psychology, pedagogy and theory and methods of labor education and technology on the implementation of democratic education in the educational process of general secondary education; development of guidelines for students on the implementation of the principles of democratic education in the lessons of labor training during pedagogical practice at school.

Key words: didactic conditions; principles of democratic education; future teacher of labor education; pedagogical conditions.

\section{REFERENCES}

1. Budas, A. (2014). Methodological conditions of efficiency of teaching of jurisprudence to students of economic specialties. Collection of scientific works of Uman State Pedagogical University named after Pavlo Tychyna, 2, 59-65.

2. Byrylova, E.A., Avdeeva, N.V. (2013). Methodological conditions of formation and development of general cultural competences at bachelors of pedagogical education in the field of life safety. Young Scientist, 8 (55), 380-383.

3. Kobernik, O.M., Yashchuk, S.M. (2015). Scientific principles of theory and methods of teaching technology. Uman: FOP "Yellow".

4. Makhamov, D. (2012). Democratization of the pedagogical process in secondary vocational schools. The main trends of development (on the materials of the pedagogical and technical college). (PhD dissertation). Dushanbe.

5. Motsak, S.I. (2011). Methodical bases of the organization of extracurricular work on history in profile classes. (PhD dissertation). Kyiv.

6. Musakaeva, Z.Z. (2006). Pedagogical conditions of humanization and democratization of school management. (Extended abstract of Doctoral dissertation). Makhachkala.

7. Nazarenko, H.A. (2016). Theory and practice of educating the culture of democracy of high school students in secondary schools. (Doctoral dissertation). Kyiv.

8. Slastenin, V.A., Isaev, I.F., Mishchenko, A.I., Shiyanov, E.N. (2002). Pedagogy. Moscow: School Press.

9. Sergeeva, T.N. (2011). Formation of democratic value orientations in the future teacher. (Extended abstract of PhD dissertation). Nizhniy Novgorod.

10. Dictionary-reference book on professional pedagogy. (2006). Ed.-order. A.V. Semenov. Odesa: "Palmyra".

11. Steshenko, V., Steshenko, B. (2018). Factors determining the pedagogical conditions for the organization of the educational process in higher education institutions. Professionalism of the teacher: theoretical and methodological aspects, 8, 27-37.

12. Khutoryansky, I.I. (2000). Pedagogical conditions for democratization of the municipal system of general education. (PhD dissertation). Tomsk.

Матеріали надійшли до редакції 04.05.2021 р.

Професіоналізм педагога: теоретичні й методичні аспекти. - Вип. 14 (Ч. 2). - Слов’янськ, 2021. 